\title{
A JUSTIÇA CÓSMICA PLATÔNICA
}

\author{
Eduardo Carlos Bianca Bittar \\ Doutor pelo Departamento de Filosofia e Teoria Geral do \\ Direito da Faculdade de Direito da Universidade de São Paulo
}

\begin{abstract}
Resumo:
Trata-se de investigar alguns aspectos pontuais da teoria platônica da Justiça, sobretudo aqueles ligados à cosmologia e à metafísica que perpassam o texto da República, em seu livro X, a partir do mito de Er (República, $525 \mathrm{a} / 621 \mathrm{~d}$ ). Com este intuito é que se direcionam as pesquisas para a mística desta concepção acerca do justo e do injusto.
\end{abstract}

\begin{abstract}
:
It is about a research of some prompt remarks of theory platonicienne of the justice, especially those attached to the cosmology and the metaphysics that cross the text of the Republic (Republic, 525 a/ $621 \mathrm{~d}$ ), in his $\mathrm{X}$ book, from the myth of Er. It is with this intention that one directs research for the mystic of this conception on the just and the unjust.
\end{abstract}

Unitermos: Justiça; retribuição; bem comum; metafísica.

Sumário:

1. Delimitação das ambições de pesquisa; 2. A transcendência da Justiça; 3 . O mito de Er; 4. A Justiça cósmica; Conclusões; Bibliografia

1. Delimitação das ambições de pesquisa

Quando se trata de investigar pontualmente a virtude da Justiça ${ }^{1}$ na concepção teórica platônica, constata-se, desde o início, a imbricação do tema com

1. De pronto, deve-se dizer que a Justiça é uma virtude, e liga-se diretamente à virtude a idéia de conhecimento (só se erra por ignorância, no lema socrático), de modo que a virtude é algo ensinável. Mas, se todo conhecimento somente pode ser dito como tal se se detiver nas Essências, e não nas aparências, então, a Justiça que se ensina é acerca do que É e não do que parece ser; em meio ao dualismo (presente em Tales, Parmênides, Heráclito, Anaxímenes, Anaximandro, Empédocles) mitológico e místico flagrante entre Bem (cuja causa é Deus e que existe como Idéia) e Mal (cuja causa é outra que não Deus e que inexiste como Idéia), a Justiça ensinável é algo que aponta para o Bem. Consulte-se a respeito destas impressões, Kelsen, A Ilusão da Justiça, 1995, pp. 01-17 e 142-152. 
pressupostos metafísicos. ${ }^{2}$ Vislumbra-se que os entrelaçamentos temáticos são incontornáveis, pois, no estudo da questão, não se pode relegar a pergunta "o que é a Justiça?" ao derradeiro plano. Deve-se enfrentá-la, sem excusas, e, justamente por isto, esbarra-se na linha de uma fronteira que desloca o problema do simples tratamento da Justiça como uma questão humana, ética, política, jurídica... para radicá-la em solo metafísico.

Assim, discutir e enfrentar o problema da Justiça na teoria platônica pressupõe que se desloque a pesquisa no sentido da abordagem do fundamento último das práticas de poder, jurídicas e políticas. Em outras palavras, à procura de um fundamento para a Justiça, sua existência e sua natureza, neste retrocesso às causas últimas da dominação, da obediência... estão, na teoria platônica, pressupostos ligados à teoria do conhecimento, à teoria da alma, à teoria das Idéias, etc. ${ }^{3}$ Nesta especulação, portanto, não se poderá deixar de encaminhar a compreensão da Justiça como sendo paite Bem Absoluto, Idéia transcendente, eterna, imutável, não-sujeita à apreensão sensível e, portanto, não-sujeita à demonstração, nem mesmo por meio da dialética. A idéia do Bem que está a governar todo kósmos noêtos representa a grande prioridade do sistema de Idéias concebido por Platão. ${ }^{4}$ É neste intento, enfim, que se lançam as presentes considerações.

$\mathrm{O}$ empreendimento, que se resume na abordagem de apenas um aspecto das preocupações platônicas acerca da Justiça, não deve, em suas

2. O acompanhamento da semântica do termo diké (e seus correlatos dikia, adikía, dikaiosýne...), dentro do contexto cultural grego, permite dizer que, historicamente, houve uma gradativa dessacralização das questōes ligadas à Justiça, que deixaram de estar tamanhamente dependentes da vontade dos deuses do Olimpo (Zeus, Thémis, Diké e outros deuses) para se fazerem questōes humanas, e, portanto, serem tratadas dentro do diálogo sócio-humano como objeto de perquirições mais racionais e menos religiosas e/ou metafísicas. O processo de dessacralizaçāo (do séc. VIII ao séc. IV a. C.) dos significados de diké, de Homero a Aristóteles, coincide com a própria modificação cultural por que passou a sociedade grega (Bittar, A teoria aristotélica da Justiça, in Revista da Façuldade de Direito da Universidade de São Paulo, v. 92, 1997, pp. 53-73). Mas, no meio deste processo, pode-se apontar Platão (sécs. IV-V a.C.) como uma exceção, pois reverte sua teoria no sentido da especulação metafisica, na tentativa de enfrentar o relativismo sofístico, incumbindo-a da tarefa de identificar a essência da Justiça, na sequeência das contribuições místicas órfico-pitagóricas.

3. De fato: "A ligação íntima entre as doutrinas platônicas da alma e da Justiça é óbvia, não apenas no fato de ele sempre apresentar uma em conjunção com a outra, especialmente na sua obra principal sobre a doutrina da alma, no Fédon, mas igualmente nas modificações pelas quais passa a doutrina da alma" (Kelsen, O que é Justiça?, 1998, p. 99).

4. "Donde mejor se ve cómo concebía él esta solución es en la República, pues toda la estructura de esta obra descansa sobre el criterio de que la idea del bien, el principio primario de todos los valores, ocupa un lugar predominante en el centro del cosmos" (Jaeger, Paidéia, 1949, III, p. 288). 
pretensões, deixar de relacionar minimamente dados importantes e conceitos-chave que participem do interesse temático, assim como não deve deixar de recolher informações relevantes que estejam em conexão com o objetivo temático. Deste modo, com pretensões delimitadas, não se visa a traçar um panorama acerca do imenso problema da Justiça em Platão, mas, sim, fazer com que a questão pontual (Justiça cósmica), eleita como objeto desta investigação, seja atravessada por considerações que introduzem carências demonstrativas durante a abordagem do tema. $^{5}$

É certo que, ao se mencionar a intenção de uma investigação sobre a Justiça em Platão, está-se a cercar uma temática tăo-vasta quanto as próprias latitudes da obra do filósofo da Academia. Isto porque a preocupação com a Justiça aparece desde as obras de juventude até as de maturidade, perpassando, com relevantes flutuações e variações semânticas de uma obra a outra, todo o conjunto dos escritos exotéricos (exoterikoi lógoí) platônicos. Então, temáticas como o Estado Ideal, o governo do rei-filósofo (philosophos), a constituição (politeía), a melhor forma de se dar leis (nómos) aos homens, as classes sociais do Estado e as partes da alma (psychê), a função do legislador (nomotétes) para o Estado, o papel da eqüidade (epiéikeia) ao lado da lei (nómos), as penas e a justificação de sua utilização pelo Estado, a Justiça como virtude (aretê), a Justiça como proporção (analogía), entre outras, seriam necessariamente trazidas para o seio da investigação, tornando-a complexa demais para que se tornasse viável.

Porém, não se trata de relegar estas temáticas, simplesmente desconsiderando-as. Trata-se, ao invés, de se abordar uma tópica (Justiça cósmica platônica), e de se apresentarem alguns comentários acerca da mesma, que absorve os demais debates laterais (Justiça e eqüidade, Justiça e democracia, Justiça no Estado...); o que se quer é ver a Justiça discutida sob o seu aspecto metafísico, que, na teoria platônica, significa o mesmo que a discussão acerca de essências (do que

5. As flutuações de significado do termo dike na história grega, literária e filosófica, são inúmeras. Mesclada às noções hierárquico-sociais à época de Homero, sedimentada como reclamo social na obra de Hesíodo, desenvolvida em várias de suas facetas nas mãos dos dramaturgos do séc. V a.C., enxertada na relatividade do discurso dos sofistas, a semântica histórica do termo diké trai qualquer lentativa de uniformização do conceito pesquisado (Cfr. Pelers, Termos filosóficos gregos: um léxico histórico, 1983, pp. 53-55, verbete dike). Mesmo na obra de um determinado filósofo, como Platão, o termo sofre inúmeras variações, dos diálogos de juventude aos de maturidade (comparar Apologia de Sócrates, Ion, Eutifron, Hípias Maior, Laques, Cármides, onde a Justiça é tratada lateralmente, com Protágoras, Górgias, República, Político, Leis, onde a Justiça é tratada frontalmente). Por isso a investigação despretensiosa deve se situar em aspectos pontuais e categóricos do problema, não devendo se alargar para toda a dimensão da obra do filósofo. 
é), e não das aparências (do que pode ser, como pode não-ser) ${ }^{6}$ Assim, tragadas no essencialismo transcendente platônico, as demais temáticas que não são abordadas frontalmente, deslocam-se como aspectos indiretos da realização da Justiça na sociedade, numa determinada constituição (politeía), em sua materialidade funcional, o que só pode significar o cumprimento e a realização das regras metafísicas que governam o kósmos.

\section{A transcendência da Justiça}

A transcendência da Justiça não se deve ao fato de ser esta uma questão desinteressante aos homens. Pelo contrário, a sociedade carece de Justiça, o homem carece de Justiça; esbarra-se, inevitavelmente, quando da constituição de um Estado, na questão da Justiça. Mais que isto, toda organização política realiza justiças ou injustiças. A Justiça perpassa os ambientes humanos, as organizações, os agrupamentos, e confere sentido à organização constitucional de todo Estado; é-lhe mesmo espinha dorsal, senão sua própria ratio essendi. Assim é que se pode dizer que se trata de uma questão sobre a qual se depositam muitos interesses humanos, sociais e éticos, e Platão não nega isto em sua teoria.

Afirmar que toda Justiça residiria em solo transcendente seria 0 mesmo que negar a possibilidade de existência de uma Justiça palpável. Assim, entre o Justo Absoluto, inalcançável de imediato, e somente contemplável como Idéia, e o Injusto Absoluto, máxima manifestação da injustiça, existe uma outra categoria, a do justo empírico, humano, realizável. ${ }^{7}$

O que ocorre verdadeiramente é que o debate acerca do justo e do injusto platônicos, ao se abrir para pressupostos metafísicos, não se exaure nos estreitos limites dos acontecimentos humanos. As dificuldades humanas em definir 0 termo "justiça" em apresentar racionalmente os limites de sua prática social, em circunscrever seus traços de modo claro na legislação, entre outras, são exatamente os motivos que justificam a necessidade de superação do relativismo conceitual (Justiça como dado entre dados), assim como da contingência da Justiça legislada,

6. Essência e aparência parece ser o eixo binário que movimenta a argumentação platônica. A este respeito, o mito da caverna (República), com sua simbologia, é esclarecedor. Consulte-se o estudo aprofundado de Findlay, La transcendencia de la caverna, 1969.

7. Cf. Kelsen, A Ilusăo da Justiça, 1995. pp. 40-61. 
no sentido de buscar-se o absolutismo conceitual (Justiça como imanência), assim como a permanência da Justiça como valor perene.

Nada disto, segundo Platão, pode ser conseguido sem a contemplação do que é definido como Real. E o ponto de partida para a constituição dos meandros desta discussão, acerca da Realidade e da Verdade, que aliás perpassa inúmeros diálogos platônicos, será o "mito de Er" apresentado, em meio a uma exposição de Sócrates a Glauco sobre arte e técnica, no final do livro X do diálogo República (525 a/ 621 d) de Platão. ${ }^{8}$

\section{O mito de Er}

A narrativa do mito, portanto, é um impositivo no excursus desta investigação. Neste sentido é que se dedica este espaço à apresentação do mito, que se refere à figura de Er, guerreiro originário da Panfilia (Ásia Menor), que, morto em uma batalha, teve seu corpo posteriormente encontrado dentre outros cadáveres de guerreiros, mas na espantosa condição de cadáver são e integro. Uma vez encontrado, reconduzido à sua pátria e velado por doze dias (dwdekataîos) (Rep., 614 a), no último destes doze dias, recobrou a vida e contou aos circunstantes o que havia visto no Hades.

A partir de então advém seu relato pessoal, tudo narrado por Sócrates, baseado nas tradições populares a respeito, de como seria a vida no Além, contando que, ao deixar o corpo, sua alma foi para um lugar maravilhoso, uma grande pradaria, onde se aglomeravam inúmeras almas, e onde se avistavam quatro buracos, dois no solo e dois no céu. Os juízes, que ali se encontravam, avistavam os justos, e a estes recomendavam de seguir à direita e para o céu, por uma das aberturas (toùs mèn dikaíous keleúein poreúesthai ten eis dexían te kaì ánw dià toû ouranoû) (Rep., $614 \mathrm{c}$ ), e avistavam, da mesma forma, os injustos, e a estes recomendavam de seguir à esquerda e para baixo, por uma das aberturas (toùs dè adíkous tèn eis aristerán te kai kátw) (Rep., 614 c). Estes mesmos juizes, que selecionavam os justos dos

8. O fato de se abordar um mito não torna a pesquisa parte de uma panacéia figurativa; o mito é tão-significativo como método, em Platão, como o diálogo e a discussão dialética. De fato: "Por vezes, abandona a discussão dialética e exprime idéias de acesso difícil por meio do mito. Este encontrava-se na tradição, servia para embelezar a exposição e repousar o espírito com sua beleza poética, exprimindo o provável ou o possível, mas não o absolutamente certo. Pensa-se que só se empregava nas obras destinadas ao público, e não ao ensino" (Pereira, Estudos de história da cullura clássica, 7a. edição. I Volume, 1993, p. 478). 
injustos, recomendaram a Er que não tomasse nenhuma das direções, mas que retornasse ao mundo e servisse de testemunha aos homens do que havia visto ali.

De uma das aberturas da terra, conta Er ter visto surgir almas sujas e empoeiradas, que contavam sofrimentos e dores, e, pelo contrário, de uma das aberturas do céu, almas puras, que contavam das maravilhas que haviam visto (tàs d'au ek toû ouranoû eupatheías diegeîsthai kaì théas amechánous tò kállos) (Rep., 615 a), todas vindas de uma longa viagem. Sócrates, em sua narrativa do relato de $\mathrm{Er}$ sobre o supraterreno, insiste em contar apenas o essencial a Gláuco, atribuindo ainda a Er outras informações acerca da vida no Além. Assim, as almas injustas pagavam, para cada injustiça cometida, dez vezes mais (dekákis); a duração de cada punição é de cem anos (vida humana); para cada boa ação, na mesma medida, a recompensa é decuplicada. A narrativa de Er sobre o sistema de punições e recompensas se baseia no testemunho de almas que, além de terem visto coisas feias e padecido coisas ruins, presenciaram grandes criminosos (parricidas, tiranos...) serem impedidos de deixar as entranhas da terra ao tentarem delas sair.

Logo em seguida a uma permanência de sete dias nesta pradaria, onde estes fatos narrados foram presenciados por Er, as almas dela se deslocaram por quatro dias, caminhando em direção a uma coluna luminosa, que se vertia em direção ao céu. Ali se avistavam Lachésis (passado), Clotho (presente) e Atropos (futuro), filhas da Necessidade, responsáveis pelo movimento dos arcos celestes. Apresentando-se, relata Er, diante de Lachésis, cada alma recebia sua sorte no porvir, e isto tendo-se em vista o reencontro próximo com um corpo carnal (archè álles periódou thnetoû génous thanatephórou) (Rep., 617 d), mas tudo não por intervenção e responsabilidade da divindade, mas sim por sua própria liberdade de escolha (aitía eloménou; Theòs anaítios) (Rep., 617 e; Timeu, 42 d); escolhendo os modelos de vida (tà twn bíwn paradeigmata) (Rep., 618 a), as almas o faziam com base em experiências e hábitos de vidas anteriores (katà synétheian gàr toû protérou biou tà pollà aireîsthai) (Rep., 620 a), selecionando o que melhor lhes conviria num futuro próximo.

Neste sentido, tendo em vista a liberdade de escolha de cada alma, podiam ser escolhidas vidas animais ou humanas (zwwn te gàr pántwn bíous kai dè kaì toùs anthrwpinous ápantas) (Rep., 618 a); após a escolha, cada alma recebia seu demônio, que lhes encaminharia nas dificuldades da vida (ekeínen d'ekástw òn eíleto daímona) (Rep., 620 d). Isto feito, o demônio de cada alma se encarregava de conduzir a sua pupila diante de Clotho e, em seguida, de Atropos, tornando 
irrevogável o destino por ela escolhido livremente, dentro de seu cabedal de responsabilidades e experiências anteriores.

Em seguida, todas as almas se apresentavam diante do trono da Necessidade, para, posteriormente, passarem pela grande planície do Léthes, onde, pela noite, beberiam da água do rio Amelete, responsável pelo esquecimento do que viram e vivenciaram. Feito este ritual, em meio à noite, após fortes estrondos e relâmpagos luminosos, cada alma é conduzida ao local onde renascerá. Er, por sua vez, não tendo bebido da água do rio Amelete (cuja água é responsável pelo esquecimento das vivências anteriores), e tendo recebido a orientação de retornar ao mundo para contar sua experiência no Além, recobrou sua consciência, tomando novamente posse de seu corpo que foi retirado de campo em meio aos andrajos de guerra, pôde, liberto do adormecimento que acomete todas as almas, trazer seus relatos sobre o que seria a responsabilidade de cada qual pelos seus atos e pelo próprio destino.

Conhecendo isto, afirma e garante Sócrates a Gláuco, pode-se ser feliz, bem como agradar os deuses, nesta terra e de imediato, e no Além, no descrito caminho de mil anos que se tem impreterivelmente de enfrentar (kai en tê chiliétei poreía, èn dielelythamen, eû práttwmen) (Rep., $621 \mathrm{~d})$.

\section{A Justiça cósmica}

Por meio deste mito, e deve-se grifar o fato de o mito representar para o discurso socrático-platônico um modus procedendi de debate de uma questão, Sócrates procura ilustrar a vivência da alma que é pouco palpável e a respeito da qual pouco se conhece: a vivência post mortem. O encerramento do texto da República com o mito parece transferir a carga e o peso da interpretação do mito ao leitor, isto porque, acredite ou-não em sua realização, o leitor se vê impressionado por suas dimensões. Os ecos do mito, e as recomendações de Sócrates no sentido de que Gláuco se empenhe em ter sempre presente esta imagem em sua mente, ribombam no vazio do término de um dos mais marcantes textos platônicos.

E o que é importante reter são os reflexos destas considerações sobre a teoria platônica da Justiça. Da calibração entre o que é humano e o que é divino, Platão extrai suas considerações sobre o justo e o injusto. A admissão de uma Realidade (divina) para além da realidade (humana), importa, também, na admissão de que existe uma Justiça (divina) para além daquela conhecida e praticada pelos 
homens. O que é inteligivel, perfeito, absoluto e imutável, pode ser contemplado, e é do resultado desta atividade contemplativa que se devem extrair os princípios ideais para o governo da politeía, tarefa delegada ao filósofo. ${ }^{9}$

Platão está consciente, ao elaborar sua doutrina, do fato de que a Justiça (divina) é inalcançável, e, portanto, irrealizável como práxis social. A Justiça é inalcançável porque se trata de algo inefável. A Justiça Absoluta é um segredo divino, ${ }^{10}$ sendo, portanto, inexprimível do ponto de vista teórico. ${ }^{11}$ Bem ao contrário do que ocorre na proposta de Aristóteles, que concede tratamento rigoroso, semântico e detalhado a cada espécie e subespécie nominada de Justiça (díkaion nómimon, dikaion phýsikon...), ${ }^{12}$ nos diálogos de Platão dedicados à questão da Justiça, que não são poucos (comparar Apologia de Sócrates, Íon, Eutífron, Hípias Maior, Laques, Cármides, onde a Justiça é tratada lateralmente, com Protágoras, Górgias, República, Político, Leis, onde a Justiça é tratada frontalmente), queda a questão sem possibilidade de receber tratamento conceitual mais sólido ou uniforme.

Mas, mesmo estando a Idéia da Justiça distante dos olhos do comum dos homens, sua presença se faz sentir desde o momento presente na vida de cada indivíduo. Existe, para além da ineficaz e relativa Justiça humana (a mesma que condenou Sócrates à morte!), uma Justiça, infalível e absoluta, que governa 0 kósmos, e da qual não se pode furtar qualquer infrator. A Justiça não pode ser tratada unicamente do ponto de vista humano, terreno e transitório; a Justiça é questão metafísica, e possui raizes no Hades (além-vida), onde a doutrina da paga (pena pelo mal; recompensa pelo bem) vige como forma de Justiça Universal.

A cosmovisão platônica, que segue rigorosamente passos pitagóricos, permite a abertura da questão da Justiça a caminhos mais largos que aqueles tradicionalmente trilhados no sentido de se determinar seu conceito. O que a proposta platônica contém é uma redução dos efeitos racionais da investigação, e

9. Onde o filósofo platônico governa não são necessárias leis, pois sua vontade é a vontade do Estado; as leis somente aparecem como um paliativo, como uma alternativa viável para a falta de um verdadeiro homem sábio. Neste caso, as leis não devem e não podem ser desobedecidas em hipótese alguma, como se afirma no Político, 300 (Kelsen, A llusão da Justiça, 1995, pp. 498-503).

10. Cf. Kelsen, A Ilusão da Justiça, 1995, pp. 497-498.

11. Cf. id. ibid., pp. 488-489.

12. Vide, a este respeito, Bittar, A teoria aristotélica da Justiça, in Revista da Faculdade de Direito da Universidade de São Paulo, v. 92, São Paulo, 1997, pp. 53-73. Ademais, consulte-se o texto de Ferraz Júnior, La noción aristotélica de justicia, in Atlântica, Madrid, 1969, março-abril, III, pp. 166194. 
uma maximização dos aspectos metafísicos do tema. ${ }^{13}$ Neste sentido, toda alma que perpassa a sombra e a incógnita da morte, encontrará seu julgamento, que será feito de acordo com os impecáveis mandamentos da Justiça. A doutrina da paga no Além dos males causados a outrem, deuses e homens, possui caráter essencialmente órfico-pitagórico, ${ }^{14}$ e é o cerne da Justiça cósmica platônica.

Desta forma, combatendo o relativismo conceitual proposto pelos sofistas, encontra Platão a raiz do problema da Justiça não no hic et nunc das práticas jurídicas e políticas humanas. Em verdade, o que faz Platão, ao teorizar sobre a matéria, é integrar as responsabilidades humanas a um movimento valorativo mais amplo que aquele que preside a organização sócio-humana. A conduta e seu regramento possuem raízes no Além (Hades), de modo que o sucesso terreno (maioria dos tiranos, homens públicos, juízes...) e o insucesso terreno (Sócrates...) não podem representar critérios de mensurabilidade do caráter de um homem (se justo ou se injusto). No reino das aparências (mundo terreno, sensivel), o que parece ser justo, em verdade, não o é, e o que parece ser injusto, em verdade, não o é. A inversão ético-valorativa operada por Platão ${ }^{15}$ faz com que todo o equilíbrio das relações humanas se baseie não em critérios palpáveis, acessiveis aos sentidos, passíveis de serem discutidos pela opinião (dóxa) $:^{16}$ o que há é que se cria uma expectativa de Justiça, somente realizável no Além, apesar de, por vezes, imediatizar-se na vida terrena.

Mais que tudo, nesta seqüência do raciocínio platônico, a Justiça como retribuição (paga pelos males causados a homens e a deuses) no Além é a doutrina

13. Assim, o que ocorre é que a noção de Justiça se funcionaliza, de modo a que scja fcita parte de uma ordem de coisas muito maior; sua importância como máximo valor humano diminui à medida em que a investigação evolui em seus aspectos metafísicos e transcendentes. De Cato, a Justiça parlicipa do Bem, Idéia Maior que tudo ordena, e para o que tudo teleologicamente se direciona, ou scja, da Idéia que congrega todas as demais virtudes (Amizade, Coragem, Amor...). A própria paga no Além é somente meio para a realização do Bem Supremo, como se pode inferir do texto da República. A respeito, consulte-se Kelsen, A Ilusão da Justiça, 1995, pp. 447-448.

14. Consulte-se, a respeito do misticismo platônico, Cornford, Mysticism and science in the pythagorean tradition, in The pre-socratics: a collection of critical essays, 1974, pp. 135-160.

15. "Platão não dá grandes garantias acerca do destino dos justos nesta vida - embora ele tenha a ccrteza de quc os deuses os não-csquecerão (Rep. 613a-b; comparar Lcis X, 899c-900b) -. mas é na vida futura que a Justiça recebe a sua recompensa suprema, tal como é descrito em termos ardentes no "Mito de Er" in República X" (Peters. Termos filosóficos gregos, 1983, p. 55, verbete dikê).

16. O que é justo não pode ser objeto de dóxa, mas somente de epistéme, c esta não é senão o conhecimento por meio da dialética; a própria massa dos homens não está em acordo quanto ao que seja a Justiça. Vide, neste sentido, Kelsen, A Ilusão da Justiça, 1995, p. 279. 
da pedagogia do agora, pois atemoriza pela possibilidade da sanção. Seja no Górgias, seja nas Leis, seja na República, a retribuição aparece como a forma providencial de Justiça cósmica. Nas Leis, sobretudo, a ordem do mundo é dada pela Justiça retributiva (Leis, 903) ${ }^{17}$ Esta é infalível. ${ }^{18} \mathrm{O}$ melhor à alma que se separa do corpo é nada dever a ninguém, pois aquele que algo dever, ainda que se esconda (Leis, 905), sob a Justiça encaminhada pela Providência Divina haverá de sucumbir. De fato, a retribuição é o modo de Justiça metafísica (República, 613), que ocorre desde o aqui e também no Além. A Justiça agrada a Deus, ${ }^{19}$ sendo que a injustiça 0 desagrada; mais que isto, a Justiça é causa de bem para aquele que a pratica, e causa de mal para aquele que a transgride. ${ }^{20}$

Sobretudo o mito final da República (mito de Er) ilustra a doutrina da paga no Além, motivo pelo qual sua narração aparece como um imperativo na construção desta investigação. De acordo com o mito narrado por Sócrates a Gláuco, as almas despidas de quaisquer ornamentos, qualificações, títulos, referências, provas de grandeza... apresentam-se a um tribunal (divino), cuja função é julgar acerca do destino de cada qual no Além, de modo a que umas justas passem à direita de Deus (gozos), outras injustas passem à esquerda e para baixo de Deus (penas); ${ }^{21}$ as almas cumprem seus ciclos num longo período de provas, durante o qual permanecem indo e vindo entre duas realidades.

Toda alma que retorna de seu ciclo tem o direito de escolher, diante de três moiras, a sorte que deseja cursar, dentro de um vasto leque de opções, podendo optar por profissões e posições sociais as mais variadas, levando-se em conta as aptidões que já possui e que já adquiriu em vivências passadas; logo em seguida submete-se a alma a beber a água do rio Ameles para o esquecimento do que viu e

17. "Enquanto identifica justiça com retribuição, Platão não apenas assume a doutrina órficopitagórica, mas aceita uma visão do povo grego que vem da Antigüidade" (Kelsen, O que é Justiça?. 1998, p. 99).

18. Cf. Kelsen, A Ilusão da Justiça, 1995, pp. 325-327.

19. Cf. id. ibid., p. 279.

20. O castigo corrige, emenda, ensina; é a única forma de correção do incorreto; também a intimidação metafísica (temeridade pelo futuro no Hades) é aliada da correção e educação das almas. Vide a este respeito, as considerações acerca da pedagogia penal de Platão no texto A Ilusão da Justiça, de H. Kelsen, 1995, pp. 305-310.

21. Está-se a utilizar da palavra Deus (Théos), no contexlo dos estudos da República, mas, há que se ressaltar que a presença de Deus é muito mais sensivel nas obras posteriores à República. Nestas Platão parece assumir todas as consequiencias diretas e indiretas do uso do termo Deus, como princípio c causa do existente, em sua reflexão. Esta é a opiniāo de Jaeger, Op. cit., p. 289. 
posterior renascimento. ${ }^{22} \mathrm{O}$ próprio renascimento, momento de união do corpo com a alma, sendo que esta está presa como a um cárcere àquele, significa a Justiça em funcionamento, mecanismo que responsabiliza cada alma por sua conduta aqui e no Além. $^{23}$

A conclusão não é outra senão a de que não se pode ser justo ou injusto somente para esta vida, pois se a alma preexiste ao corpo, é porque também subsiste à vida carnal, de modo que ao justo caberá o melhor e ao injusto o pior. Aqui residem esporos da doutrina órfico-pitagórica e de um dualismo escatológico. Ao justo, a Ilha dos bem-aventurados, ao injusto, o Tártaro (Górgias, 447). ${ }^{24}$ Neste sentido, o mecanismo é implacável, pois toda alma comparecerá diante de um tribunal, que sentenciará os acertos e os erros, determinando o fim de cada qual no Além. $^{25}$

Mas, neste quadrante de reflexões, ainda se encontra espaço para as considerações acerca da Justiça que é praticada entre os homens. Não-só a Justiça (Divina) está presente entre os homens, como também a Justiça (humana), uma vez que esta nada mais é que cópia da Justiça (Divina); instável e imperfeita, só pode ser algo que deriva do conhecimento instável e imperfeito que o homem possui da Verdade, da Realidade, do que É, de acordo com a teoria metafísica do conhecimento exposta no Mênon e no Fedro. ${ }^{26}$ A existência da Justiça (Divina) não desmerece a existência da Justiça (humana). Pelo contrário, aquela é fundamento para a obediência desta; a ordem estatuída por uma constituição (politeía) deve ser seguida como preceito de valor divino, e isto pois seu fundamento reside na transcendência da própria Justiça Absoluta; esta obediência, mesmo às leis iniqüas, deve ser irrestrita (Críton, 50), pois também Sócrates submeteu-se à sentença

22. Daí a idéia fundamental da doutrina platônica de que a concepção de Justiça é inata ao homem quando de seu nascimento, pois conheceu o que é o justo e o injuslo no Além, disto tendo se esquecido transitoriamente, cabendo ao filósofo, por maiêutica, trazer à tona este conhecimento previamente adquirido, reavivando apenas o que já se conhece por experiências anteriores.

23. Cf. Kelsen, A Ilusão da Justiça, 1995, pp. 315-323.

24. Esta mesma reflexão reaparece no começo e no fim da República.

25. Cf. Kelsen, A Ilusão da Justiça, 1995, pp. 300-304.

26. Cf. id. ibid., pp. 203-218. 
condenatória que injustamente lhe fora imposta (Apologia de Sócrates). ${ }^{27}$ Assim, as leis positivas vêm justificadas metafisicamente, e a legitimidade da organização criada por elas deriva desta ordem sobrenatural. ${ }^{28}$ As leis transitórias que se inspiram nas regras da Justiça hão de ser obedecidas sob qualquer condição.

A ordem política platônica se estrutura como uma necessidade para a realização da Justiça, um imperativo para o convívio social, ${ }^{29}$ onde governados obedecem e governantes ordenam. ${ }^{30} \mathrm{E}$, nesta ordem, onde uns obedecem e outros ordenam, deve haver uma cooperação entre as partes para que se realize a Justiça. A alma tripartite, cuja estrutura é dada pelo Fédon, é feita paradigma funcional para a explicação da estrutura do próprio Estado (Rep., 368 e ss.), onde a razão deve imperar sobre a paixão, sob pena de o cocheiro não-conseguir corrigir o curso da alma desgarrada pelos instintos, como narrado no Fedro, 246. A divisão do trabalho é a regra de Justiça no Estado Ideal; três classes dividem-se em três atividades (política; defesa; economia), não podendo haver interferência de uma classe na atividade da outra (Rep., 592); a interferência representa a injustiça. ${ }^{31}$ Isto, pois, cada classe corresponde a uma parte da alma, e a alma racional, aliada à epitimética, deve governar. Neste sentido, a Justiça na cidade é ordem; a desordem é sinônimo de injustiça. ${ }^{32}$ A Justiça é a saúde do corpo social, pois onde cada um cumpre o que lhe é dado fazer, o todo se beneficia desta complementaridade.

O Estado Ideal platônico descrito sistematicamente na República é apenas meio para a realização da Justiça. ${ }^{33}$ Mas, de fato, este Estado não-existe na

27. Na teoria aristotélica da Justiça, o respeito à máxima Justiça, ou seja, à Justiça que regula a vida da comunidade (dikaion nominón), chamada justiça total, é o respeito à própria comunidadc. 0 desrespeito aos seus comandos só pode representar o desrespeito à ordem estatuída para o controle das condutas humanas.

28. Cf. Kelsen, A Ilusão da Justiça, 1995, pp. 504-519.

29. Para que se perceba de mais perto as nuances que estão a governar o cosmo, a cidade e o homem, leia-se, obrigatoriamente, Rachel Gazolla de Andrade. Platão: o cosmo, o homem e a cidade. 1994, onde se encontrará excelente análise da teoria platônica.

30. Cf. Kelsen, A ilusão da jusliça, 1995, pp. 238-241.

31. Cf. id. ibid., p. 462.

32. "La Justicia, en efecto, la justicia en la ciudad, consiste simplemente en que cada una de las clases sociales que hemos dicho, o más concretamente los hombres a ellas pertenecientes, hagan lo que les corresponde: los guardianes, que gobiernen; los soldados, que combatan y los de la clase económicamente productiva, que produzcan" (Robledo, Platón: los scis grandes temas de su filosofia, 1993, p. 559).

33. Cr. Kelsen, A Ilusâo da Justiça, 1995, pp. 453-457. 
Terra, e sim no Além, como modelo a se inspirar (Rep., 592). Neste Estado, a Constituição (politeía) é apenas instrumento da Justiça, pois estabelece uma ordem jurídica. De qualquer forma, para Platão, o Estado Ideal deve ser liderado não por muitos (democracia), uma vez que a multidão não-sabe governar, ${ }^{34}$ mas por um único (teocracia), o filósofo, o sábio, pois este contemplou a Verdade, e está apto a realizá-là socialmente. Aqui, poder e filosofia (platônica) se aliam.

Nas Leis, ${ }^{35}$ diferentemente do que ocorre no movimento textual da República, o Estado aparece como uma realidade concreta, de modo que a tendência final do escrito, organizado por Filipe de Opunto, é a paidéia. Na República, o Estado, na verdade, é assumido apenas paradigmaticamente; a possibilidade de sua ocorrência é reduzida. ${ }^{36}$ Do supramodelo paradigmático do Estado irrealizável para o Estado palpável, há um acréscimo de concretude considerável na teoria política platônica.

Conclusões

Antes de distanciar o metafísico do físico, Platão cuida de reafirmar a unidade teológica como causa daquilo que está submetido à corrupção e daquilo que não-está. Desta forma, é claro que a própria legislação, as práticas políticas, as formas, os regimes de Estado... encontram fundamento último na própria ordenação cósmica. Aquilo que é transcendente tudo perpassa, de modo que a metafísica desta concep̧̧ão soma à noção de Justiça humana uma outra, a da Justiça Divina, que a tudo preside, que a tudo governa, uma vez que Deus é a medida de todas as coisas ( $o$ dè theòs emin pántwn chremátwn métron àn eíe málista).

Em Leis, 645 b, Deus figura como legislador e inspirador da legislação humana. ${ }^{37} \mathrm{~A}$ própria questão que abre o debate do diálogo não é outra senão se Deus é ou-não legislador (624 a) ${ }^{38}$ De fato, consta que, e nas Leis (715 e)

34. Cf, id. ibid., p. 458.

35. Há que se concordar com aqueles que sustentam como argumento em favor da autenticidade das Leis o fato de este diálogo não-anular o Estado Ideal da Repuiblica, e sim se adicionar àquela proposta feita com pinceladas mais idealistas (Robledo, Platón: Ios seis grandes temas de su filosofía, 1993, p. 589).

36. Cf. Jaeger, Paidéia, 1949, III, pp. 273-276.

37. pol in w de h para qewn tinoj h par anqrwpou tou gnontoj tauta I ogon parabousan.

38. A resposta do cretense é afirmativa, no sentido de que Zeus é responsável pela legislação (Qeoj, xene, Qeoj, wj ge to dikaiotaton ei pein). 
isto é expresso, que Deus é o princípio, o meio e o fim de todas as coisas ( $o$ mèn dè theós, wsper kaì o palaiòs lógos, archén te kaì teleutèn kaì mésa twn óntwn apántwn échwn), ou, ainda nas Leis $(716 \mathrm{c})$, que Deus é a medida de todas as coisas (o dè theòs emin pántwn chremátwn métron àn eíe málista), diferentemente do que acreditavam os sofistas, com destaque para Protágoras, para quem o homem era 0 princípio de todas as coisas, das que são porque são e das que não-são porque nãosão. ${ }^{39}$ Em poucas palavras, sobretudo nas obras de velhice, Deus aparece, na expressão de Jaeger, como o "pedagogo universal" 40

A doutrina platônica, não-obstante as diferenças pontuais que distanciam partes da obra, que dilaceram a busca de unidade do pensador, que dificultam o conhecimento de conjunto do filósofo e de suas preocupações, aparece como um pensamento coerente na medida em que dentro dela a ratio essendi do Estado não é outra senão a paidéia; onde Deus governa como pedagogo, e tudo se direciona teleologicamente para o Bem Absoluto, é certo que a educação tem de ser o fim das estruturas humanas e políticas. Assim, ao Estado é delegada está função primordial de ensinar almas, e em sua atuação, em sua existência, em seu proceder estão presentes poderes para isto (seja para corrigir, seja para punir, seja para fazer expiar, seja para melhorar...); educação e Estado ${ }^{41}$ andam entrelaçados. ${ }^{42}$ Assim, também, a ética e a moral estão na base do justo e do injusto, assim como da própria política.

39. De fato: "Así concebido, el concepto de Dios se convierte en centro y luente de toda legislación y ésta en su expresión directa y su realización terrenal. Dios se revela y actúa en el cosmos del Estado, como en el de la naturaleza" (Jaeger, Paidéia, 1949, III, p. 313).

40. Cf. Jaeger, Paidéia, 1949, III, pp. 314-315.

41. A solução medianeira dada por Aristóteles ao problema da educação é diferente daquela proposta por Platão nas Leis. A educação deve ser pública e privada, para Aristóteles (Politica; Ethica Nicomachea); não-só pública, pois, a adesão voluntária à atitude ética depende do animus do agente, de maneira que apesar de uma legislação perfeita induzir à formação de homens perfeitos, isto praticamente jamais ocorrerá sem que os cidadãos se sintam voluntariamente compelidos ao dever. Éthos é resultante da inculcação da virtude na reiteração de ações do homem, pelo próprio homem, e não pela legislação ou a partir da legislação. $O$ hábito virtuoso provém desde a mais tenra idade e deve estar acompanhado de theoría e práxis. Basta, pois, no tocante a estas questões, o que ficou dito. A respeito do problema da educação predominantemente pública em Platão, comenta-se: "En realidad, la creación de un sistema complelo de educación elemental, considerado como la paideia del pueblo y como base de la alta educación de que se había ocupado en sus obras anteriores, constituye una de las más audaces innovaciones de Platón, digna de este gran genio educativo" (Jaeger, Paideia, III, 1949. p. 318).

42. E na base desta relação estaria o éros na movimentação do todo. A este respeito, vide Kelsen, A Ilusão da Justiça, 1995, pp. 245-266. 
Bibliografia

ANDRADE, Rachel Gazolla de. Platão: o cosmo, o homem e a cidade. Petrópolis: Editora Vozes, 1994.

BITTAR, Eduardo Carlos Bianca, A teoria aristotélica da Justiça, in Revista da Faculdade de Direito da Universidade de São Paulo, v. 92, São Paulo, 1997, pp. 53-73.

BITTAR, Eduardo Carlos Bianca. A Justiça em Aristóteles. São Paulo: Forense Universitária, 1999.

CORNFORD, F.M. Mysticism and science in the pythagorean tradition, in The presocratics: a collection of critical essays, Anchor Press/ Doubleday, Garden City, Nova York, 1974, pp. 135-160.

FERRARI, G. R.F. Moral fecundity: a discussion of A. W. Price, Love and friendship in Plato and Aristotle, in Oxford Studies in Ancient Philosophy, v. IX, Clarendon Press, Oxford, 1991, pp. 169-184.

FERRAZ JÚNIOR, Tércio Sampaio. La noción aristotélica de Justicia, in Atlântica, Madrid, 1969, março-abril, III, pp. 166-194.

FINDLAY, J. N. La transcendencia de la caverna. Versión española de Jesús Díaz. Madrid: Gredos, 1969.

GUTHRIE, W. K. C. Los filósofos griegos: de Tales a Aristóteles. $4^{\mathrm{a}}$ edição. Trad. de Florentino M. Torner. México: Fondo de Cultura Económica, 1967.

JAEGER, Werner. Paidéia: los ideales de la cultura griega, III. Versión española de Wenceslao Roces. México, Buenos Aires: Fondo de Cultura Económica, 1949.

KELSEN, Hans. A Ilusão da Justiça. Trad. de Sérgio Tellaroli. Martins Fontes: São Paulo, 1995.

KELSEN, Hans. O que é Justiça?: a Justiça, o direito e a política no espelho da ciência. Trad. de Luís Carlos Borges. São Paulo: Martins Fontes, 1998.

MAGALHÃES-VILHENA, Vasco de. O problema de Sócrates: O Sócrates histórico e o Sócrates de Platão. Lisboa: Fundação Calouste Gulbenkian, 1984.

PEREIRA, Maria Helena da Rocha. Estudos de história da cultura clássica. $7^{\text {a }}$ edição. I volume (Cultura Grega). Lisboa: Fundação Calouste Gulbenkian, 1993.

PETERS, F. E. Termos filosóficos gregos: um léxico histórico. $2^{\mathrm{a}}$ edição. Trad. de Beatriz Rodrigues Barbosa. Lisboa: Fundação Calouste Gulbenkian, 1983. 
PLATO. Laws, I-VI. Translated by R. G. Bury. Cambridge, London: Harvard University Press, 1994.

PLATON. Protagoras. Euthydème. Gorgias. Menexène. Ménon. Cratyle. Traduction, notices et notes par Émile Chambry. Paris: Garnier Frères; Flammarion, 1967.

PLATONE. La repubblica. A cura di Giuseppe Lozza. Milano: Arnoldo Modadori Editore, 1990.

ROBLEDO, Antonio Gómez. Platón: los seis grandes temas de su filosofía. México: Fondo de Cultura Económica, 1993. 




Platão: a Justiça Cósmica 